\title{
Sclerite fusion in the problematic early Cambrian spine-like fossil Stoibostrombus from South Australia
}

\author{
ChRISTIAN B. SKOVSTED, GLENN A. BROCK \& TIMOTHY P. TOPPER
}

\begin{abstract}
New collections of the problematic spine like fossil Stoibostrombus crenulatus Conway Morris \& Bengtson from the Mt. Scott Range and Wilkawillina Gorge in the central Flinders Ranges, South Australia contain fused sclerite composites. In each fused specimen the spines are merged along their lateral margins and the orientation of the spines is almost identical. These new specimens confirm that Stoibostrombus spines were dermal sclerites, arranged in lateral pairs or transverse rows. The nature of the animal secreting the spines remains elusive, but available evidence suggest that it was an ecdysozoan animal, possibly a palaeoscolecid worm. - Key words: Early Cambrian, South Australia, scleritome, Ecdysozoa, Palaeoscolecida.
\end{abstract}

Skovsted, C.B., BRock, G.A. \& TOPPER, T.P. 2011. Sclerite fusion in the problematic early Cambrian spine-like fossil Stoibostrombus from South Australia. Bulletin of Geosciences 86(3), 651-658 (3 figures). Czech Geological Survey, Prague. ISSN 1214-1119. Manuscript received October 15, 2010; accepted in revised form April 17, 2011; published online July 14, 2011; issued September 30, 2011.

Christian B. Skovsted (corresponding author), Department of Palaeozoology, Swedish Museum of Natural History, Box 50007, SE-104 05 Stockholm, Sweden \& Department of Earth Sciences, Palaeobiology, Uppsala University, Villavägen 16, SE-752 36 Uppsala, Sweden; Christian.Skovsted@nrm.se • Glenn A. Brock \& Timothy P. Topper, Department of Biological Sciences, Macquarie University, Sydney, New South Wales 2109, Australia; glenn.brock@mq.edu.au, timothy.topper@mq.edu.au

Small Shelly Fossils (SSF) are major constituents of earliest Phanerozoic shelly faunas (Bengtson et al. 1990, Gravestock et al. 2001, Missarzhevsky 1989, Qian \& Bengtson 1989, Rozanov et al. 1969, Skovsted 2006). Under this "catch-all" label hides a large number of small scale-, capor spine-shaped fossils that often represent disarticulated parts of larger skeletons that remain more or less problematic in terms of zoological affinities. However, some examples can be identified, at least in a broad sense, and may represent early stem group members of modern phyla. In many cases, clues to biological affinity were only provided after exceptional preservation revealed the structure of the complete or partially complete skeleton, or scleritome, of the organism. Such was the case for the net like microfossil, Microdictyon, which was discovered to represents dorsal sclerites on a lobopodian (Chen et al. 1989, 1995) and the cap-shaped tommotiids (e.g. Eccentrotheca and Paterimitra) which represent sclerites of stem group brachiopods (Skovsted et al. 2008, 2009b, 2011).

Stoibostrombus crenulatus Conway Morris \& Bengtson in Bengtson et al. (1990) has remained one of the most enigmatic Small Shelly Fossils. It is only known from lower Cambrian successions in South Australia (Arrowie and Stansbury basins), but is a relatively common fossil in acid resistant residues ranging from the Pararaia tatei tri- lobite Zone to Toyonian-equivalent horizons in the uppermost lower Cambrian. The cone- or spine-shaped fossils of Stoibostrombus are curved to varying degrees and often exhibit an overhanging apex. Each spine is always open at both ends but often do not exhibit any obvious natural or complete margins. The most conspicuous feature of Stoibostrombus is the unusual external ornament of pustulose nodes (diagnosed as "pulvinate" by Conway Morris \& Bengtson in Bengtson et al. 1990, p. 145) or crenulated transverse ridges.

Conway Morris \& Bengtson (in Bengtson et al. 1990) compared Stoibostrombus crenulatus to Dimorphoconus granulatus, a poorly known Ordovician fossil with multiple dorsal spines (Donovan \& Paul 1985), suggesting that S. crenulatus represented dorsal sclerites of a vagrant benthic animal. Brock \& Cooper (1993) noted similarities in general shape and ornament with uthaphosphids suggestive of a palaeoscolecid affinity for Stoibostrombus, a hypothesis also supported by Conway Morris (2008). However, Demidenko (in Gravestock et al. 2001) preferred to compare Stoibostrombus to sensory papillae of modern onychophorans. Here, we describe the first occurrence of naturally fused spines of $S$. crenulatus. Although no new unequivocal evidence in favour of any particular phylogenetic hypothesis is presented, the new specimens for the first 

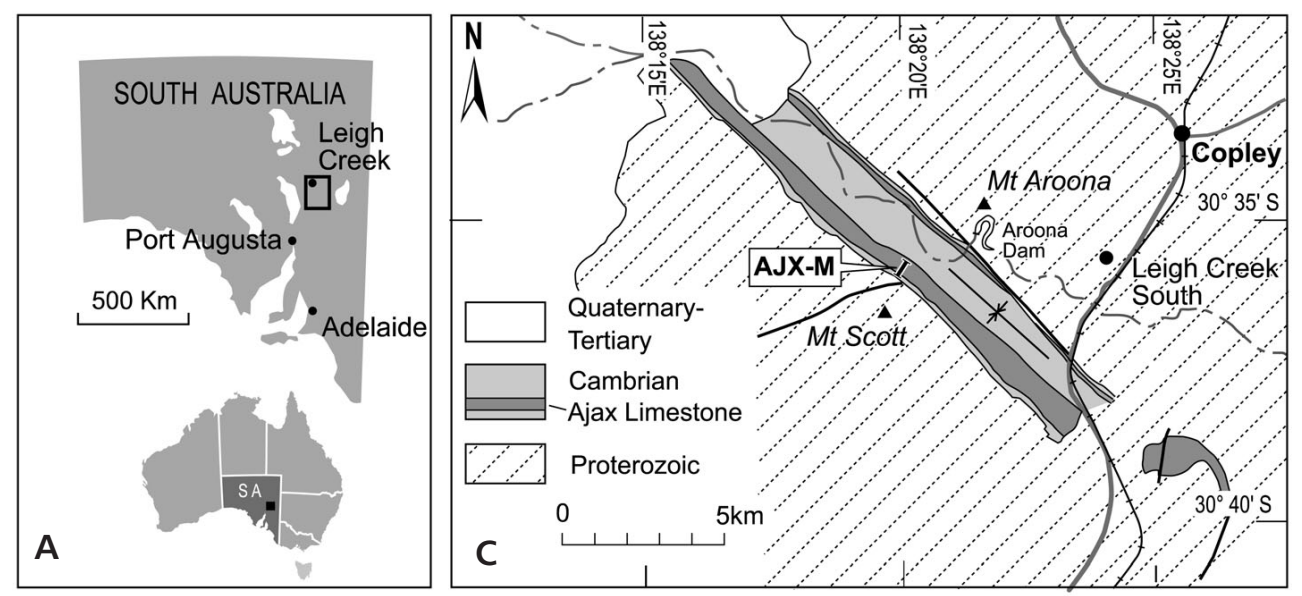

Figure 1. Map figure showing provenance of sampled sections. - A - map showing location in South Australia. - B generalised map of the Flinders Ranges area showing the location of field areas. $\bullet \mathrm{C}$ - detailed map of the Mt. Scott area with the location of section AJX-M indicated. $\bullet$ D - detailed map of the Wilkawillina Gorge area showing location of Wilkawillina type section.
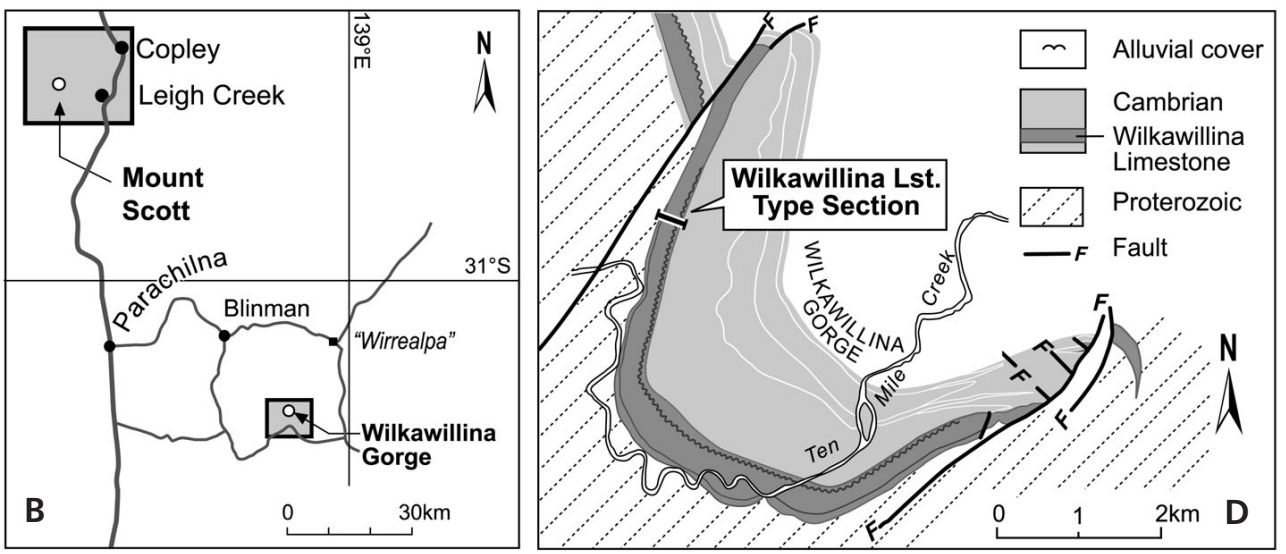

time reveal information on the actual arrangement of spines in Stoibostrombus.

\section{Material and geological setting}

Large collections of SSF's recovered from multiple sections and localities with exposed lower Cambrian rocks in the Arrowie Basin amassed by the authors during the last decade includes great numbers of Stoibostrombus crenulatus (Fig. 1). One of the fused spine pairs described herein (SAMP46285, Fig. 2A-D) is from horizon AJX-M/415, equivalent to $232.07 \mathrm{~m}$ (true thickness) above the base of section AJX-M measured through the Ajax Limestone on the northern side of Mt. Scott Range, South Australia. The AJX-M section is located at co-ordinates $30^{\circ} 35^{\prime} 49^{\prime \prime} \mathrm{S}$, $138^{\circ} 19^{\prime} 59.3^{\prime \prime} \mathrm{E}$ [WGS84] equivalent to section M of Gravestock (1984, fig. 2). The stratigraphy and lithology of the Ajax Limestone at section AJX-M has been summarized by Brock et al. (2006), Skovsted et al. (2009a, 2011), Topper et al. (2011). The carbonate-dominated Ajax Limestone is approximately $280 \mathrm{~m}$ thick at AJX-M and conformably overlies the siliciclastic Parachilna Formation. Parts of the rich faunal assemblage of the AJX-M section have been described intermittently over the last few deca- des including the archaeocyaths (Gravestock 1984), trilobites, molluscs, sponge spicules and SSFs (Bengtson et al. 1990, Topper et al. 2011). More recently, the stem group brachiopod Mickwitzia sp. (Skovsted et al. 2009a), the tommotiid Eccentrotheca (Skovsted et al. 2011), and a bivalved arthropod assemblage (Topper et al. 2010 b) have been described from this section. The biostratigraphic range of Stoibostrombus crenulatus is largely restricted to the Pararaia tatei trilobite biozone in this section.

Three fused specimens were recovered from samples collected from the Second Plain Creek Member of the Wilkawillina Limestone type section (Daily 1956) in Wilkawillina Gorge by the late Brian Daily in the early 1970s. The section occurs along a small tributary to the north-west of 10 Mile Creek within the syndepositional Bunkers Graben (Fig. 1) and the base of the 69 m section through the Second Plain Creek Member occurs at a karstic boundary associated with the regionally significant Flinders Unconformity (Gravestock \& Shergold 2001). The base of the section is estimated at $31^{\circ} 15^{\prime} 44.9^{\prime \prime} \mathrm{S}, 138^{\circ}$ 52' 39.8" E - WGS84; see also Clarke 1986a, fig. 2; Gravestock 1984, fig. 1). The carbonates of the Second Plain Creek Member range from packstones and grainstones near the base into interbedded wackestones 
and lime mudstones (Clarke 1986b). One fused specimen (SAMP46288, Fig. 3) was recovered from horizon WILK/N, collected at $58 \mathrm{~m}$ above the base of the section and two composite specimens (SAMP46286, Fig. 2E-G; SAMP46287, Fig. 2H-J) are derived from horizon WILK/Q, some $65 \mathrm{~m}$ above the base of the section. Trilobites have not been described from the Second Plain Creek Member, but associated SSF and lateral stratigraphic alignments suggest an age equivalent to the uppermost Abadiella huoi biozone or lowermost $P$. tatei biozone.

\section{Composite spines}

Isolated sclerites of Stoibostrombus crenulatus from the Stansbury Basin and Arrowie Basin were described in detail and extensively illustrated by Brock \& Cooper (1993), Conway Morris \& Bengtson (in Bengtson et al. 1990) and Topper et al. (2009). Beyond the occurrence of the fused specimens described herein, no new information relating to the general morphology, microstructure or composition of S. crenulatus was revealed by our studies.

The composite specimens each contain two or three spines fused in a lateral file with their apices oriented in roughly the same directions. However, in other respects the four specimens differ dramatically, and are described separately below.

In SAMP46285 the two spines are long and slender cones with an apical diameter of about $30 \mu \mathrm{m}$ and an apical angle of $15^{\circ}$ and $16^{\circ}$ respectively (Fig. 2A-D). Adapically the spines coalesce along an apparently straight line (Fig. 2A). The base of the fused sclerite composite is a dome-like sub-spherical structure bounded by uneven and apparently broken margins (Fig. 2C). The characteristic ornament of serrated nodes and discontinuous transverse ridges is equally expressed on each spine before the zone of fusion and is only weakly deflected adapically at the junction (Fig. 2D). The internal surface of the sclerite composite exhibits a uniform ornament of shallow pits except for the zone of fusion which is clearly demarcated as a wide transverse ridge (Fig. 2B).

SAMP46286 preserves one large spine laterally attached to a smaller spine (approximately half the height and diameter at level of junction; Fig. 2E-G). Despite the size difference the spines have approximately the same proportions and both spines are gently curved in the same direction although they are nearly vertical in relation to the base of the specimen (Fig. 2E). Both spines have broken apices. The spines are joined along a slightly curved line which continues as a gentle fold towards the aperture of the specimen. The ornament of nodes and transverse ridges is only slightly disturbed across the line of junction (Fig. 2G).

Three spines are fused in SAMP46287 (Fig. 2H-J). The spines are arranged in a transverse file of decreasing size with the slightly overhanging apices oriented in the same direction (Fig. 2H). The largest spine is a broad, symmetrical cone (apical angle $42^{\circ}$ ) and is much larger than the other two spines (Fig. 2I). The second and third spines are of similar dimensions and morphology, but the third spine is broken relatively close to their common base. Both the first and the second spines have well preserved apices with smooth rimmed circular apertures (diameter $35 \mu \mathrm{m}$; Fig. 2J). The junctions between the spines are partly obscured but the ornament of the basal areas does not appear to be strongly disturbed across the zones of junction. On the posterior side of the specimen the ornament suggests that the two smaller spines were united first and these were fused to the largest spine as a unit (Fig. 2I).

In SAMP46288 two spines of sub-equal size are united (Fig. 3). Both spines exhibit the same morphology, intermediate between narrow spine-shaped and broad cone-shaped (apical angle about $30^{\circ}$; Fig. 3B). However, one of the spines (slightly smaller) is fused to the other at a position somewhat posterior of the other spine, and the directions of the apices diverge by $14^{\circ}$ from each other (Fig. 3A). In lateral view it is apparent that the posterior spine is rotated posteriorly in relation to the anterior spine (Fig. 3B). The zone of junction between the spines is a semi-circular arc defined by the posterior spine and exhibits a complicated pattern of folds and crevices affecting the posterior side of the base of the anterior spine (Fig. 3C). However, closer to the aperture the base of both spines are joined more smoothly. The apex of the anterior spine is damaged but the posterior spine preserves a smooth rimmed circular aperture (diameter $25 \mu \mathrm{m}$ ).

\section{Stoibostrombus reconstructed}

The recovered specimens, both fused composites and single spines vary extensively in general morphology and ornamentation. Most specimens from the Second Plain Creek Member at Wilkawillina Gorge have an ornament which includes large, nodose plates (Figs 2G, 3D). Such specimens were referred to by Conway Morris \& Bengtson (in Bengtson et al. 1990) as Stoibostrombus cf. crenulatus but later the new name Stoibostrombus mirus Demidenko in Gravestock et al. (2001) was introduced to accommodate them. We note that within a single collection, specimens of both types occur together, as well as specimens of apparently intermediate morphologies. In the absence of detailed analysis of variability and occurrence patterns we prefer to unite all specimens in a single species.

Although the four specimens with multiple fused spines described above differ from each other they reveal new details concerning the arrangement of the spines in 


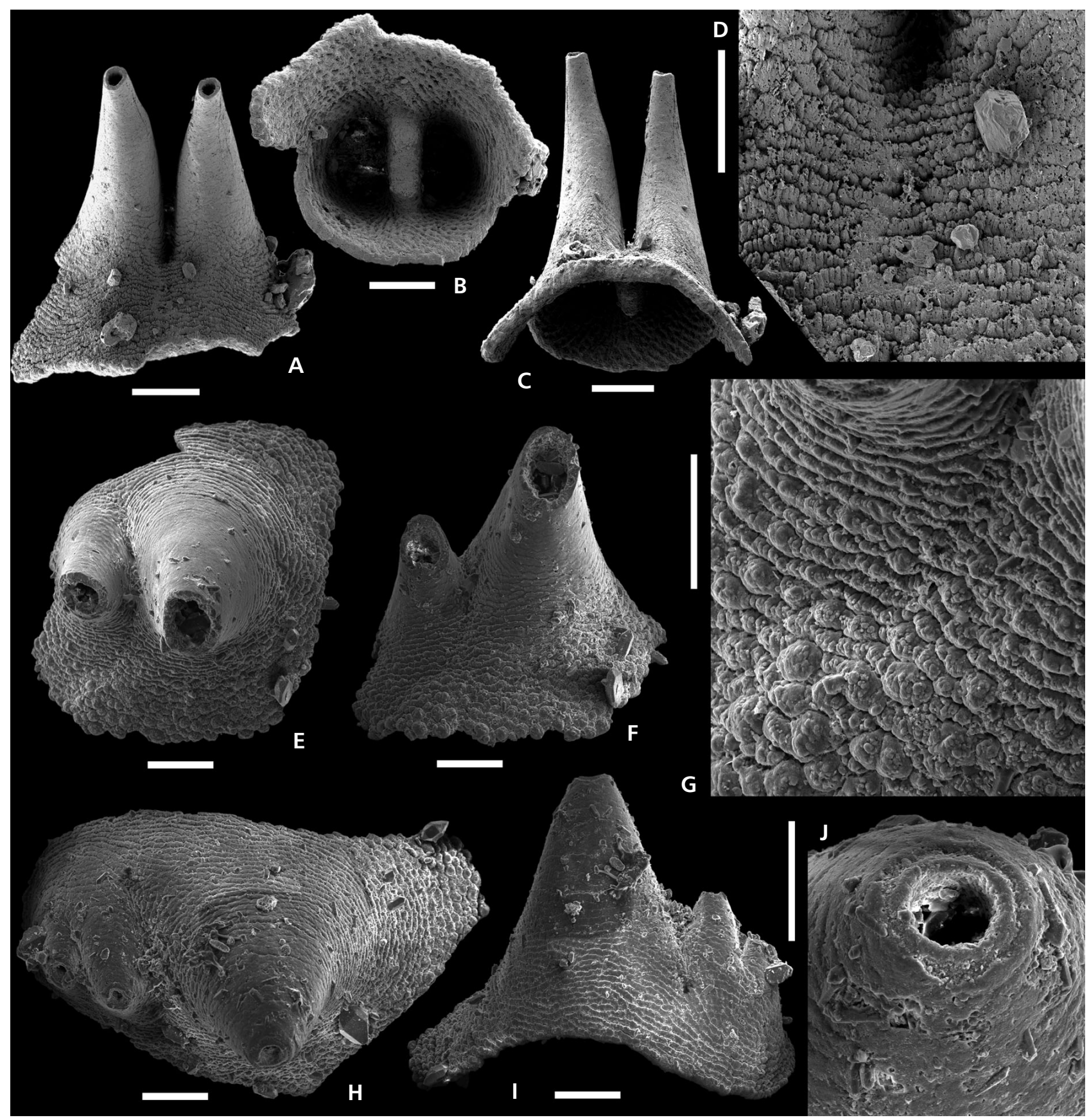

Figure 2. Stoibostrombus crenulatus Conway Morris \& Bengtson in Bengtson et al. (1990) from the Arrowie Basin, South Australia. All scale bars except D, G, J equal $100 \mu \mathrm{m}$. A-D - SAMP46285, sample AJXM 415, Mt. Scott. A - oblique anterior view; B - apertural view; C - anterior view; D - detail of junction between spines, scale bar equals $50 \mu \mathrm{m}$. $-\mathrm{E}-\mathrm{G}$ - SAMP46286, Sample Wilk Q, Wilkawillina Gorge. E - dorsal view; F - anterior view; $\mathrm{G}$ - detail of junction between spines, scale bar equals $50 \mu \mathrm{m}$. $\bullet \mathrm{H}-\mathrm{J}$ - SAMP46287, Sample Wilk Q, Wilkawillina Gorge. H - dorsal view; I - posterior view; $\mathrm{J}$ - detail of apex of largest spine, scale bar equals $50 \mu \mathrm{m}$.

scleritome of Stoibostrombus. Three specimens have spines joined together side by side or in lateral file with uniform spine orientation (SAMP46285-03). The junctions between spines are smooth and the spines are set on a common dome-shaped base. In SAMP46288 the junction between the spines display evidence of disturbance and spine displacement. In lateral view, this fused specimen suggests that the posterior spine was displaced posteriorly and rotated as it was pressed into the base of the anterior spine. Apically of the zone of junction the posterior spine retains its integrity and seems to have been displaced as a complete solid structure. The anterior spine is more strongly 


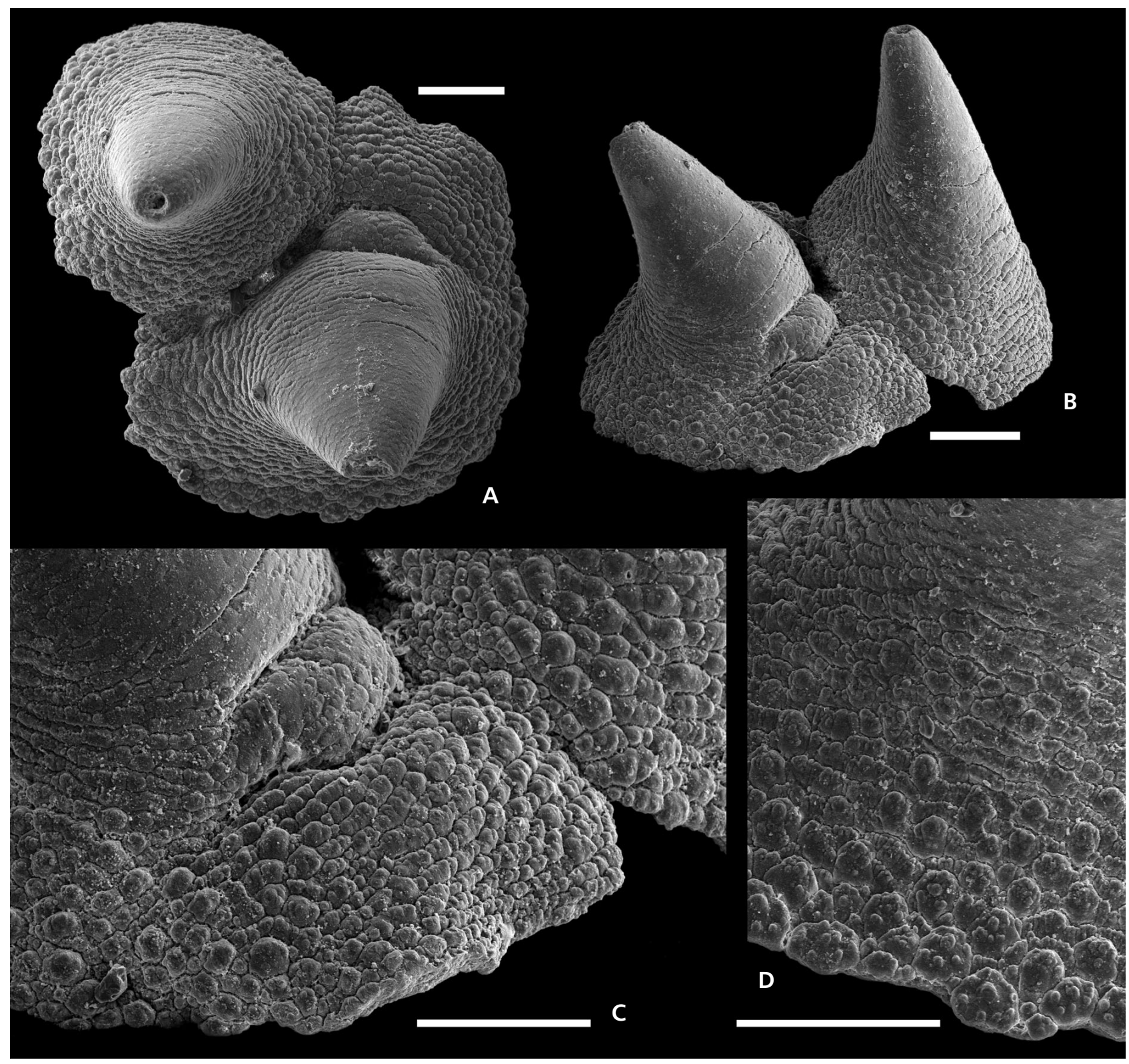

Figure 3. Stoibostrombus crenulatus Conway Morris \& Bengtson in Bengtson et al., 1990. • A-D - SAMP46288, Sample Wilk O, Wilkawillina Gorge, Arrowie Basin, South Australia. All scale bars equals $100 \mu \mathrm{m}$. A - dorsal view; B - oblique posterior view; C - detailed view of zone of junction between spines; D - detail of shell ornament on posterior part of sclerite base.

deformed and seems to have accommodated the posterior spine by folding of its spine base. However, lateral to the folds the spine bases of both spines seem to grade more smoothly into each other.

The available composite specimens indicate that the spines of Stoibostrombus were arranged in lateral rows with all spines oriented in the same direction. Each spine, or spine composites in fused specimens, originally formed a dome-shaped mineralised structure (sclerite) with well-defined margins. The rounded internal ridge in SAMP46285 represents the zone of junction of the fused spines and is situated deep inside the internal cavity of the dome-shaped spine base and clearly demonstrates that fusion occurred in connection with the mineralisation of the sclerites. In the case of SAMP46288 two adjacent spines were affected by lateral compression at the time of sclerite formation, which caused one of the spines to be displaced backwards and rotated. A single specimen of S. crenulatus from the Ajax Limestone at Mt. Scott described by Conway Morris \& Bengtson (in Bengtson et al. 1990, fig. $96 \mathrm{E}, \mathrm{F}$ ) preserves a large flat node or plate on the lateral side of the main spine. This structure may also correspond to a second spine, being deformed during an early stage of shell secretion. 


\section{Biological affinity of Stoibostrombus}

A subset of early Cambrian SSF's are believed to be phosphatic by original composition. Among these groups, such as the cap-shaped tommotiids (see Skovsted et al. 2008, 2009b) or the tubular Hyolithellus (see Skovsted \& Peel 2011), grew by marginal accretion and most likely represent early stem group members of the lophotrochozoan clade. Other phosphatic SSF's lack evidence of incremental growth and are more likely to represent early members of the Ecdysozoa. Microdictyon (see Chen et al. 1995, Topper et al. 2011), net-like sclerites from a lobopodian, belong to this group. In the case of Stoibostrombus the original composition is uncertain, but is likely to be phosphatic. This hypothesis is supported by the fact that the spines themselves are much more frequently preserved in acid residues than their internal moulds, which is opposite the case for the superficially similar hyoliths (cone-shaped, mollusc-like calcareous problematica; see Bengtson et al. 1990). The external ornament of transverse ribs which are often present on parts of the spines or spine bases in Stoibostrombus may be superficially similar to comarginal growth increments of shells growing by marginal accretion. However, the ribs are often discontinous, and adapically disintegrate into discrete 'pulvinate' nodes or plates. This type of ornament is similar to the cancellate ornament of Mongolitubulus Missarzhevsky, 1977 (see Skovsted \& Peel 2001). However, Mongolitubulus specimens are now known to represent broken carapace spines from bradoriid arthropods (Skovsted 2005, Topper et al. 2007).

Unfortunately, the new information on sclerite arrangement in Stoibostrombus does not reveal much concerning the gross scleritome morphology of the animal secreting the spines or its biological affinity. Conway Morris \& Bengtson (in Bengtson et al. 1990) compared Stoibostrombus to Dimorphoconus Donovan \& Paul, 1985, known from aggregates of cone-like shells from the lower Ordovician of Shropshire. The granular cones of Dimorphoconus were arranged in a central zone with broad cones and a lateral rim with densely spaced long and narrow cones (Donovan \& Paul 1985, fig. 3). This arrangement is quite different from that of Stoibostrombus as interpreted herein, and the two fossils are probably not closely related. The characteristic ornament of Stoibostrombus, especially forms incorporating large plates, is reminiscent of a host of organophosphatic caps and plates (including Uthaphospha Müller \& Miller, 1976, Kaimenella Märss, 1988 and Hadimopanella Gedik, 1977 etc.) that are generally thought to represent dermal plates of palaeoscolecid worms (see review in Topper et al. 2010a). Of these taxa Stoibostrombus is most closely comparable to Chalasiocranus Brock \& Cooper, 1993 from slightly younger, Toyonian-equivalent rocks of South Australia and the widespread Uthaphospha (see review in Hinz et al. 1990). In palaeoscolecids, phosphatic sclerites are usually arranged in transverse rows defined by the distinct annulations of the vermiform body (Hinz et al. 1990, Topper et al. 2010a).

The transverse arrangement of the spines could be explained if Stoibostrombus was interpreted as a palaeoscolecid worm. However, the dome-shaped spine base of both single Stoibostrombus spines and the fused composite specimens described above, suggest that the scleritome would be much more strongly ornamented than in any bona fide palaeoscolecids known from the fossil record (see Conway Morris 2008 and Topper et al. 2010a for recent reviews). At the present time we can only conclude that the proposed relationship of Stoibostrombus with ecdysozoans is supported by the available evidence and that Stoibostrombus may be most closely related to palaeoscolecid worms.

\section{Acknowledgements}

The authors wish to thank Graham Ragless owner of Beltana Station for permission to collect material from the Ajax Limestone at Mt. Scott Range and to the South Australian Museum for permission to use the collections of the late Brian Daily from Wilkawillina Gorge. J.R. Paterson, B. Jonak, M. Fuller, R. Callow, P. Cockle are thanked for assistance in the field. Funds from the Swedish Research Council (VR) to CBS and a Macquarie University Research Development Grant to GAB are gratefully acknowledged. Two external reviewers, J. Bergström and R. Wrona are thanked for constructive evaluations of the manuscript.

\section{References}

Bengtson, S., Conway Morris, S., Cooper, B.J., Jell, P.A. \& Runnegar, B.N. 1990. Early Cambrian fossils from South Australia. Memoirs of the Association of Australasian Palaeontologists 9, 1-364.

Brock, G.A., Alexander, E.M., Paterson, J.R., Jago, J.B. \& Gatehouse, C.G. 2006. Mt Scott Range and Ajax Mine, 40-43. In JAGo, J.B. \& Wenlong Zhang (eds) South Australia 2006. XI International Conference of the Cambrian Stage Subdivision Working Group, Geological Society of Australia, South Australian Division, Adelaide.

Brock, G.A. \& CoOPER, B.J. 1993. Shelly fossils from the Early Cambrian (Toyonian) Wirrealpa, Aroona Creek, and Ramsay Limestones of South Australia. Journal of Paleontology 67, 758-787.

Chen Junyuan, Hou Xian-Guang \& Lu HaOzhi 1989. Early Cambrian netted scale-bearing worm-like sea animal. Acta Palaeontologica Sinica 28, 1-16. [in Chinese with English summary]

Chen Junyuan, Zhou Guiquing \& RamsköLd, L. 1995. The Cambrian lobopodian Microdictyon sinicum. Bulletin of the National Museum of Natural Science 5, 1-93. 
Clarke, J.D.A. 1986a. Subdivision of the lower part of the Wilkawillina Limestone, eastern Flinders Ranges. Quarterly Geological Notes, Geological Survey of South Australia 97, $12-16$.

Clarke, J.D.A. 1986b. Stratigraphy and sedimentology of the upper part of the Wilkawillina Limestone, Wilkawillina Gorge, Flinders Ranges. Quarterly Geological Notes, Geological Survey of South Australia 100, $2-7$.

Conway Morris, S. 2008. The cuticular structure of the 495-Myr-old type species of the fossil worm Palaeoscolex, $P$. piscatorum (?Priapulida). Zoological Journal of the Linnean Society 119, 69-82. DOI 10.1111/j.1096-3642.1997.tb00136.x

DAILy, B. 1956. The Cambrian in South Australia, 91-147. In RodGers, J. (ed.) El Sistema Cambrico, su paleogeografia y el problema de su base, Report $20^{\text {th }}$ International Geological Congress, Mexico 2.

Donovan, S.K. \& Paul, C.R.C. 1985. A possible new armoured worm from the Tremadoc of Sheinton, Shropshire. Proceedings of the Geological Association 96, 87-91.

DOI 10.1016/S0016-7878(85)80016-X

GediK, I. 1977. Conodont stratigraphy in the Middle Taurus. Bulletin of the Geological Society of Turkey 20, 35-48. [in Turkish with English abstract]

Gravestock, D.I. 1984. Archaeocyatha from lower parts of the Lower Cambrian carbonate sequence in South Australia. Memoir of the Association of Australasian Palaeontologists 2, $1-139$.

Gravestock, D.I., Alexander, E.M., Demidenko, Y.E., Esakova, N.V., Holmer, L.E., Jago, J.B., Lin Tianrui, MelniKOVA, L.M., PARKhaEV, P.Y., RoZANOV, A.Y., UShatinSKAYA, G.T., Zang Wenlong, Zhegallo, E.A. \& Zhuravlev, A.Y. 2001. The Cambrian Biostratigraphy of the Stansbury Basin, South Australia. Transaction of the Palaeontological Institute, Russian Academy of Sciences 282, 1-344.

Gravestock, D.I. \& Shergold, J.H. 2001. Australian Early and Middle Cambrian sequence biostratigraphy with implications for species diversity and correlation, 105-136. In ZHURAVLEV, A.Y. \& Riding, R. (eds) The Ecology of the Cambrian radiation. Columbia University Press.

Hinz, I., Kraft, P., Mergl, M. \& Müller, K.J. 1990. The problematic Hadimopanella, Kaimenella, Milaculum and Utahphospha identified as sclerites of Palaeoscolecida. Lethaia 23, 217-221. DOI 10.1111/j.1502-3931.1990.tb01362.x

MÄrss, T. 1988. Early Palaeozoic hadimopanellids of Estonia and Kirgizia (USSR). Proceedings of the Academy of Sciences of the Estonian SSR, Geology 37, 10-17.

Missarzhevsky, V.V. 1977. Konodonty (?) i fosfatnye problematiki kembriya Mongolii i Sibiri, 10-19. In TATARINov, L.P. et al. (eds) Bespozvonochnye Paleozoya Mongolii. Nauka, Moscow. [in Russian]

MissarZHEVSKY, V.V. 1989. Drevnejshie skeletnye okamenelosti i stratigrafiya pogranichnykh tolshch dokembriya i kembriya. Trudy Geologicheskogo Instituta 443, 1-238. [in Russian]

MÜLlER, K.J. \& MilleR, J.F. 1976. The problematic microfossil Utahphospha from the Upper Cambrian of the western United
States. Lethaia 9, 391-395.

DOI 10.1111/j.1502-3931.1976.tb00979.x

PeEL, J.S. 1991. The Classes Tergomya and Helcionellida, and early molluscan evolution. Grønlands Geologiske Undersøgelse, Bulletin 161, 11-65.

QiAn Yi \& BENGTSON, S. 1989. Palaeontology and biostratigraphy of the Early Cambrian Meishucunian Stage in Yunnan Province, South China. Fossils and Strata 24, 1-156.

Rozanov, A.Y., Missarzhevsky, V.V., Volkova, N.A., Voronova, L.C., Krylov, I.N., Keller, B.M., KorolyuK, I.K., Lendzion, K., Michniak, R., Pykhova, N.G. \& Sidorov, A.D. 1969. Tommotskij yarus i problema nizhnej granitsy kembriya. Trudy Geologocheskogo Instituta Akademia Nauk SSSR 206, 1-380. [in Russian]

Skovsted, C.B. 2005. A carapace of the bradoriid arthropod Mongolitubulus from the Early Cambrian of Greenland. GFF 127, 217-220. DOI 10.1080/11035890501273217

Skovsted, C.B. 2006. Small shelly fauna from the Upper Lower Cambrian Bastion and Ella formations, North-East Greenland. Journal of Paleontology 80, 1087-1112.

DOI 10.1666/0022-3360(2006)80[1087:SSFFTU]2.0.CO;2

Skovsted, C.B., Brock, G.A., Holmer, L.E. \& Paterson, J.R. 2009a. First report of the Early Cambrian stem group brachiopod Mickwitzia from East Gondwana. Gondwana Research 16, 145-150. DOI 10.1016/j.gr.2009.02.002

Skovsted, C.B., Brock, G.A., Paterson, J.R., Holmer, L.E. \& BuDD, G.E. 2008. The scleritome of Eccentrotheca from the Lower Cambrian of South Australia: lophophorate affinities and implications for tommotiid phylogeny. Geology 36, 171-174. DOI 10.1130/G24385A.1

Skovsted, C.B., Brock, G.A., Topper, T.P., Paterson, J.R. \& Holmer, L.E. 2011. Scleritome construction, biofacies, biostratigraphy and systematics of the tommotiid Eccentrotheca helenia sp. nov. from the early Cambrian of South Australia. Palaeontology 54, 253-286.

DOI 10.1111/j.1475-4983.2010.01031.x

Skovsted, C.B., Holmer, L.E., Larsson, C.M., Högström, A.E.S., Brock, G.A., TopPer, T.P., Balthasar, U., Petterson Stolk, S. \& PAterson, J.R. 2009b. The scleritome of Paterimitra: an Early Cambrian stem group brachiopod from South Australia. Proceedings of the Royal Society of London B 276, 1651-1656. DOI 10.1098/rspb.2008.1655

Skovsted, C.B. \& Peel, J.S. 2001. The problematic fossil Mongolitubulus from the Lower Cambrian of Greenland. Bulletin of the Geological Society of Denmark 48, 135-147.

Skovsted, C.B. \& Peel, J.S. 2011. Hyolithellus in life position from the Lower Cambrian of North Greenland. Journal of Paleontology 85, 37-47. DOI 10.1666/10-065.1

Topper, T.P., Brock, G.A., Skovsted, C.B. \& PAterson, J.R. 2009. Shelly fossils from the lower Cambrian Pararaia bunyerooensis Zone, Flinders Ranges, South Australia. Memoirs of the Association of Australasian Palaeontologists 37, 199-246.

Topper, T.P., Brock, G.A., Skovsted, C.B. \& PAterson, J.R. 2010a. Palaeoscolecid scleritome fragments with Hadimopanella plates from the Early Cambrian of South Australia. Geological Magazine 147, 86-97.

DOI 10.1017/S0016756809990082 
Topper, T.P., Brock, G.A., Skovsted, C.B. \& Paterson, J.R. 2011. Microdictyon plates from the lower Cambrian Ajax Limestone of South Australia: Implications for species taxonomy and diversity. Alcheringa, online only.

DOI 10.1080/03115518.2011.533972

Topper, T.P., Skovsted, C.B., Brock, G.A. \& Paterson, J.R. 2007. New bradoriids from the lower Cambrian Mernmerna Formation, South Australia: systematics, biostratigraphy and biogeography. Memoirs of the Association of Australasian Palaeontologists 33, 67-100.

Topper, T.P., Skovsted, C.B., Brock, G.A. \& Paterson, J.R. 2010b. The oldest bivalved arthropods from the early Cambrian of South Australia: systematics, biostratigraphy and biogeography. Gondwana Research 19, 310-326. DOI 10.1016/j.gr.2010.05.012 